mately 2500 reports relating to beta-blockers other than practolol (Eraldin) have been received. There have been reports of rashes or dry eyes associated with the use of all the drugs in this group, but in most cases the signs and symptoms have cleared when treatment was withdrawn.

The Committee has received no evidence that any of the currently available beta blockers produce reactions of comparable severity to practolol, but in order to confirm this and also to exclude the possibility that serious adverse reactions of other types are occurring the Committee on Safety of Medicines would urge doctors to continue to report all untoward events occurring in patients on beta-blocking agents.

\begin{tabular}{|c|c|c|}
\hline Betacardone & (sotalol) & $\begin{array}{l}\text { Duncan Flockhart } \\
\text { and Co }\end{array}$ \\
\hline Betaloc & (metoprolol) & Astra Chemicals \\
\hline Blocadren & (timolol) & $\begin{array}{l}\text { Merck Sharp and } \\
\text { Dohme }\end{array}$ \\
\hline Inderal & (propranolol) & ICI \\
\hline Lopresor & (metoprolol) & $\begin{array}{l}\text { Geigy Pharma- } \\
\text { ceuticals }\end{array}$ \\
\hline Sectral & (acebutolol) & May and Baker \\
\hline Sotacor & (sotalol) & $\begin{array}{l}\text { Bristol } \\
\text { Laboratories }\end{array}$ \\
\hline Tenormin & (atenolol) & $\begin{array}{l}\text { Stuart Pharma- } \\
\text { ceuticals }\end{array}$ \\
\hline Trandate & (labetalol) & $\begin{array}{l}\text { Allen and } \\
\text { Hanburys }\end{array}$ \\
\hline Trasicor & (oxprenolol) & Ciba Laboratories \\
\hline Slow Trasicor & (oxprenolol) & Ciba Laboratories \\
\hline Visken & (pindolol) & Sandoz Products \\
\hline
\end{tabular}

London EC2

\section{What kind of cot death?}

SIR,-The reports on the aetiology of cot deaths in your leading article (18 March, p 671) and in the subsequent correspondence (22 April, p 1054; 6 May, p 1216) have not yet suggested a relationship between the state of mind of the mother before the event and the loss of her baby.

In six cases in which a patient has been referred to me for emotional problems in pregnancy or the puerperium the child of that pregnancy has died with a finding of cot death. Four of these babies were already on an at-risk register because of the mothers' expressed ambivalence to the baby and the extremely disrupted marital situation. Two had older siblings who had been previously taken into care for part of their lives because the mother was not caring for them properly. In three cases the local authority had been actually warned that something was likely to happen to the baby who eventually died.

What these cases had in common was an ambivalence towards the child who died and a home situation which was so disrupted by emotional problems that it was easy to see that symptoms in a baby could be overlooked or misinterpreted, feeds made up incompetently, and normal conditions of hygiene not adhered to. The question must be raised as to whether in a proportion of cot death the mental disturbance of the mother plays any part in the situation.

London W2

Elizabeth Tylden

SIR, - With reference to your leading article (18 March, p 671) I would like to put forward my observations on this subject.
I offer support to families in which a cot death has occurred. While listening to these families give an account of the final hours of the child's life I became aware that many of them had not actually been looked at for some hours. I then began asking when they had actually last seen their baby. I heard of a mother who had a child sleeping in her room, yet got up dressed, and went and made coffee withou glancing at the baby. Another family had a young baby in the car with them; after driving for some time without a backward glance at the carry-cot they unloaded the car before looking at the baby. A final example is of an 8week-old baby who had not been seen by its mother for 13 hours.

In these cases the social history has shown that there were other factors present that would lead one to believe that the baby was at some risk. It would appear that some mothers pay much less attention to their babies than others I feel that the mother's ambivalence about the conception, difficulties experienced during birth, problems in bonding, and the mother's depression may all lead to her feeling the need to distance herself from the child. I suspec that near-miss cot-death babies have mothers who are vigilant about their babies and are therefore more likely to notice them when they stop breathing and stimulate them. There may be a group of babies with poor respiratory control who also have less vigilant mothers, like the ones I have described, who are less likely to notice a pale, blue or apnoeic baby and so lose the opportunity to stimulate the child.

The fact that parents had not looked at very young babies for a long period before they were found dead occurred in a sufficient number of cases to make me wish to put this idea forward for consideration. I would be interested to hear from anyone who has similar observations as I hope to make a more detailed study.

\section{Department of Social Work,} Charing Cross Hospital (Fulham),
London W6

P E Hinton

\section{Vitamin $E$ and malignant hyperthermia}

SIR,-I wish to report a case of malignant hyperthermia occurring under general anaesthesia in a patient taking vitamin $\mathbf{E}$ which he had obtained from a health food store. The exact dosage is not known but was probably in the region of $200 \mathrm{IU}$ (equivalent to $200 \mathrm{mg}$ of $\alpha$-tocopheryl acetate) twice daily. A blood sample taken before the operation was later reported to have a serum vitamin $\mathrm{E}$ concentration of $19.4 \mathrm{mg} / \mathrm{l}$ (normal range $5 \cdot 2-11.4 \mathrm{mg} / \mathrm{l}$ ).

The patient, aged 69 , was to have a cystoscopy and Millin's prostatectomy. $\mathrm{He}$ had had an appendicectomy and inguinal hernia repair in "the 1940 s." Of the anaesthetics, it is known only that the induction agent was given rectally. He was given pethidine and promethazine premedication and anaesthetised with thiopentone, suxamethonium nitrous oxide, and halothane. The trachea was sprayed with lignocaine and intubated; relaxation was maintained with D-tubocurarine. After $1 \frac{3}{4} \mathrm{~h}$ a transfusion reaction was suspected because of a rise in pulse rate. The operation was completed, but because of the patient's general condition he was kept on the operating table and ventilated with oxygen. The rectal temperature $2 \mathrm{~h}$ after induction was $39 \mathrm{C}$ and remained static for the next $25 \mathrm{~min}$ when it suddenly rose, reaching $42 \mathrm{C}$ at the time of cardiac arrest, 2 h 50 min after induction. Arterial blood taken before the sudden rise in temperature showed pH 6.94, $\mathrm{PCO}_{2} 12.6 \mathrm{kPa}(94.7 \mathrm{~mm} \mathrm{Hg})$, and base excess $-9.8 \mathrm{mmol} / 1$. Treatment was atten $p$ ted with surface cooling, intravenous sodium bicarbonate, and dexamethasone but was unsuccessful.

Careful inquiry among the patient's seven siblings and their children has failed to reveal any death during anaesthesia, so a hereditary predisposition to malignant hyperthermia is unlikely. Dr F R Ellis of the Malignant Hyperthermia Investigation Unit has suggested that the vitamin $E$ which this patient was taking predisposed him to the development of the malignant hyperthermia syndrome. The purpose of this brief report is to alert anaesthetists to this possibility; they may wish to monitor temperatures during operations in patients who are taking vitamin $\mathbf{E}$ or health products such as wheatgerm oil which are rich in vitamin $\mathrm{E}$.

Philip James

\section{Anaesthetic Department,}

Anaesthetic Department,
Royal Isle of Wight County Hospital,
Ryde, IOW

\section{Psychological evaluation in cases of self-poisoning}

SIR,-The recent papers by $\mathrm{Dr} R$ Gardner and others (17 December, $p$ 1567) and by Dr D R Blake and Professor J R A Mitchell (22 April, $p$ 1032) highlight the increasing problem of self-poisoning and question the psychiatrist's role in assessment and follow-up

Dr Blake and Professor Mitchell even doubt that self-poisoners are patients in the conventional sense in that they have not asked for treatment; but they are surely as much patients as accident victims, for example, the majority of them more so, as we find that approximately $30 \%$ are currently receiving psychiatric treatment and $60 \%$ have consulted their general practitioner in the four weeks before the overdose. Indeed, selfpoisoning is often an expression of dissatisfaction with conventional methods of referral and treatment, so it is no surprise that in $\mathrm{Dr}$ Blake and Professor Mitchell's series the default rate in those referred to a psychiatric outpatient clinic was as high as $43 \%$.

Bearing in mind the findings of Barraclough et al that $41 \%$ of completed suicides had a previous episode of self-poisoning the two papers, far from invalidating the Hill Committee recommendations, would seem to underline their importance, in particular the need for designated treatment centres where all available help can be concentrated. Selfpoisoners are for the most part impulsive people with a low tolerance to stress; over $60 \%$ in our experience are facing an acute marital crisis, and delay in referral for even a few days can mean that the critical time for intervention has passed. Whether the help is to be given by nurses, physicians, or psychiatrists seems immaterial, but I agree with Dr Blake and Professor Mitchell that the same team should be involved throughout, and intervention is clearly simpler in a compact unit where information can be readily co-ordinated.

In this general hospital an average of 400 self-poisoners a year are admitted to a specialised four-bedded unit run jointly by physicians and psychiatrists where the nurses do much of the work of assessment, taking an initial history, talking to visitors, and offering a 24-h Samaritan-type service with phone-in or walk-in help following discharge. One or more psychiatrists attend daily and interview patients and relevant family members or when there are no relatives, the social worker, health visitor, or other key figures already in- 
volved. Some patients may have spent time in an intensive treatment unit or in a medical ward before transfer, but $75 \%$ are discharged within $48 \mathrm{~h}$ of admission to the unit, approximately $15 \%$ to psychiatric hospitals.

Outpatient follow-up is now carried out in the unit, which has reduced the default rate to less than $5 \%$, and over the past three years the relapse rate, defined as repeat of selfpoisoning within 12 months, has fallen to less than $10 \%$.

JOY WeST

St Helier Hospital,

Carshalton, Surrey

Barraclough, B, et al, British fournal of Psychiatry, 1974, 125, 355.

\section{Treatment of chlonorchiasis}

SIR,-Your timely leading article on liver fluke infection (29 April, p 1091) draws attention to the problem of infection with Clonorchis sinensis in countries like Britain and Canada, which have appreciable numbers of Chinese immigrants, but makes no reference to a recent investigation in New York City in which a single stool examination from each of 150 Chinese-born residents showed that $26^{\circ} \%$ were infected with this liver fluke. ${ }^{1}$ Subsequent correspondence with the senior author of this report has revealed that no effective treatment is available for these patients in the USA.

In a letter in $1975^{\circ}$ I reported that excellent results had been obtained at the Hospital for Tropical Diseases in London using a supply of hexachloroparaxylol (HPX) which I had obtained from a colleague in China (where the drug is freely available) and at the same time I drew attention to the fact that this drug was unobtainable in the West. Since then appeals to Hoechst Pharmaceuticals to remarket their product (Hetol) have failed and I have been equally unsuccessful in persuading a leading British pharmaceutical company to approve the manufacture of HPX, even though the company's research department found the drug to be non-toxic to laboratory animals. Since the publication of that letter I have corresponded with physicians in Britain, Canada, the United States, Switzerland, West Germany, and even Hong Kong, all complaining of inability of any alternative drug of value in treating clonorchiasis. At this very moment I know of a proved case in London urgently in need of treatment. Is there no pharmaceutical company in Britain willing to meet this challenge and is the NHS prepared to let this problem go by default?

W H JOPLING

London SW 16

1 Kammerer, W S, et al, Tropical Doctor, 1977, 7, 105.

2 Jopling, W H, British Medical fournal, 1975, 3, 767.

\section{Prognostic value of oculovestibular reflex}

SIR,-In their interesting paper $\operatorname{Dr} M A$ Hanid and others (22 April, p 1029) emphasise the importance of observing oculovestibular responses (OVR) in patients in hepatic coma. They conclude that "the prognostic value of the OVR in fulminant hepatic failure was absolute." Our own coma study ${ }^{1-3}$ to which they refer has now been extended to include 500 patients and our experience of the behaviour of OVRs in hepatic coma differs somewhat from that of Dr Hanid and his colleagues. Of 51 patients in hepatic coma, 19 fulfilled the criteria of fulminant hepatic coma. Of the whole group only four patients had absent OVRs at the time of initial assessment and one of these recovered from coma.

There are a number of possible reasons for our differing results. We accept an OVR as negative only if there is no response after injection of $100 \mathrm{ml}$ of ice-cold water into the auditory canal. Secondly, the effect of drugs other than paralytic agents must be considered in evaluation of the OVR, particularly in patients with hepatic disease, in whom the metabolism of drugs may be retarded. However, the main discrepancy between our results must depend on our differing interpretations of the word prognosis.

Our observations on OVRs were made with a view to evaluating this sign as a predictor of final outcome. Dr Hanid and his colleagues appear to have monitored the OVR in the course of the illness and they observed its disappearance as deterioration progressed. All dying patients at some stage will lose the OVR and we would submit that as an early predictor of outcome in hepatic coma these responses are of less value than they imply.

\section{N E F Cartlidge} David Bates

Department of Neurology,

Royal Victoria Infirmary
Newcastle upon Tyne

Department of Medicine,

ROBIN KNILL JONES

Caronna, J J, et al, Transactions of the American Neurological Association, 1975, 100, 25.

${ }^{3}$ Bates, D, et al, Annals of Neurology, 1977, 2, 211.

SIR,-Dr M A Hanid and others in their recent article (22 April, $p$ 1029) stress what they call the absolute prognostic value of the oculovestibular reflex in fulminant hepatic failure. By this they imply that the absence of any movement of the eyes in response to irrigation of either ear with iced water implies an inevitably fatal outcome. They go on to generalise their argument by quoting a similar totally adverse prognostic implication in head injuries $^{1}$ and in medical (including other metabolic) causes of coma. ${ }^{2}$ In a recent study ${ }^{3}$ of coma in childhood Seshia et al came to an identical conclusion: of 75 children, all four who had absent ocular motility using ice caloric testing died irrespective of the presence of other signs of brainstem function.

Any exceptions to "absolute" rules must be recognised, especially when the question is one of life or death. We therefore briefly report a single case ${ }^{4}$ of very severe diabetic coma in which total neurological recovery followed earlier complete absence of oculovestibular reflexes.

A 12!-year-old girl with a seven-day history of thirst was found unconscious in bed on the morning of 2 November 1975 and admitted to the intensive therapy unit of this hospital. She was in shock with unrecordable blood pressure, temperature $39.0 \mathrm{C}$, in grade IV coma with no responses except sluggish pupil light reactions, but had shallow respirations with a fruity odour. After rapid infusion of isotonic saline the peripheral circulation improved, blood pressure came within normal limits, and core temperature fell to normal. At this stage the diagnosis of hyperosmolar diahetic coma had been confirmed (blood glucose $180 \mu \mathrm{mol} / 1$ $(3240 \mathrm{mg} 100 \mathrm{ml}$ ), plasma osmolality $430 \mathrm{mmol} \mathrm{kg}$, $\mathrm{pH} 7.02$ ) and the neurological examination was repeated in full..$^{5}$ All neurological reactivity was absent apart from some pupil light reaction, intact oculocardiac reflex and spontanecus regular respiration. In particular, irrigation of either ear with large quantities of iced water induced no ocular movements and doll's eye responses wer absent. On this basis she was regarded as having a pure metabolic coma, and treated with $6 \mathrm{U}$ of soluble insulin intravenously and intramuscularly and then $4 \mathrm{U}$ intramuscularly hourly. Within $3 \mathrm{~h}$ she gained some tonic ocular deviation on ice calorie testing, and she was obeying commands by $48 \mathrm{~h}$. Extensive dependent ischaemic skin lesions which may have reflected her extreme hyperglycaemia ${ }^{4}$ healed with scarring, but she made a complete neurological and psychological recovery (Wechsler testing on 23 February 1976: verbal scale 118, performance 111, full scale IQ 115.)

Your readers will be well aware that poisoning can abolish all neurological reactivity. It is vital to remember that severe brainstem dysfunction may also occur in metabolic coma and that it should be entirely reversible if structural damage from brain swelling can be prevented by meticulous therapy.

It is a pleasure to thank Dr Oman Craig for permission to report this case.

J B P STEPHENSON K Evelyn Byrne

Royal Hospital for Sick Children,

Glasgow

Poulsen, J, and Zilstorff, K, Acta Neurologica Scandinavica, 1972, $\mathbf{4 8}, 282$. Neurological Association, 1975, 100, the American Seshia, S S, Seshia, M M K, and Sachdeva, R K.
Developmental Medicine and Child Neurology, 1977, 19, 614.

Craig, O, Childhood Diabetes and Its Manag
p 221 and fig 32. London, Butterworth, 1977 .

Plum, F, and Posner, J B, The Diagnosis of Stupor and Coma, 2nd edn. Philadelphia, Davis.

\section{Confidentiality of medical records}

SIR,-In their paper on self-poisoning in Nottingham (22 April, p 1032) Dr D R Blake and Professor J R A Mitchell state that "the casualty department staff keep their records on a triplicate form, the third copy of which is processed by the Trent Regional Health Authority in Sheffield for research purposes."

This quotation prompts the question whether the second and third copies include the patient's names and addresses. If they do, other questions arise: (1) Who keeps the second copies? (2) Are the patients warned (for instance, by a large notice in the casualty department) that information about their visit to that department will be sent to the regional health authority? (3) Does this procedure happen in other regions? (4) If so, should I, as an employee of the North-west Thames Region, make sure that I take my overdose in another region, lest my employer regard me as a mental health risk? And since three of the Thames regions have their offices in the same building, will I even be safe in, for example, the North-east Thames Region?

\section{P TReves Brown}

Radlett, Herts

\section{Price of survival in childhood leukaemia}

SIR,-We were interested in your leading article (11 February, p 321) and the letter from Dr P G F Swift and others (15 April, p 986) on the price of survival in childhood leukaemia. The initial endocrine study by our group' showed impaired growth hormone (GH) responses to hypoglycaemia in leukaemic children with acute lymphoblastic leukaemia (ALL) several years after they had received cranial irradiation (DXT) with a dose of 2500 